INDEPENDENT JOURNAL OF MANAGEMENT \& PRODUCTION (IJM\&P)

http://www.ijmp.jor.br $\quad$ v. 11, n. 5, Special Edition IFLOG 2019 -September 2020 ISSN: 2236-269X

DOI: 10.14807/ijmp.v11i5.1299

\title{
PRODUCTION PLANNING AND CONTROL (PPC): PRODUCTION POINTING SYSTEM DEPLOYMENT, USE AND UNFOLDING
}

\author{
José Henrique de Andrade \\ Instituto Federal de Educação, Ciência e Tecnologia de São Paulo - \\ IFSP, Brazil \\ E-mail: jose.andrade@ifsp.edu.br \\ Francisco Andrea Simões Braga \\ UNIARA, Brazil \\ E-mail: franciscoasb@yahoo.com.br \\ Luciano Campanini \\ Federal University of São Carlos, Brazil \\ E-mail: lucianoc@dep.ufscar.br \\ Josadak Astorino Marçola \\ UNIP, Brazil \\ E-mail: josadak@gestareconsultoria.com.br \\ Bruna Carvalho Nunes Rocha \\ Instituto Federal de Educação, Ciência e Tecnologia de São Paulo - \\ IFSP, Brazil \\ E-mail: bruna.bcnr@gmail.com
}

Submission: 2/29/2020 Accept: 3/2/2020

\section{ABSTRACT}

The growing need for efficiency and effectiveness in production systems management has increased the importance of processes and activities related to Production Planning and Control (PPC). Several authors point out that the more dynamic, competitive market, with higher demands from consumers and the increasing insertion of technology to support decision making, make the need for robust management processes imperative. In line with this scenario, the present work aims to present the report of a process of implementation, use and the consequences of a production pointing system. To achieve the proposed objective, a literature review was conducted on the topics of interest and a case study in a company that manufactures hospital medical products in the interior of São Paulo state. As main results, it was observed that the adoption and evolution of a production pointing system generated significant gains for the company's Production Control and increased maturity in terms of Production Management, 
DOI: 10.14807/ijmp.v11i5.1299

but required significant efforts and investments to maintain and evolve the production deploying process.

Keywords: PPC; production control; production pointing system

\section{INTRODUCTION}

The management of productive systems has become increasingly complex. Several aspects justify this increase in complexity, among them the configuration of a more dynamic, competitive market, with greater demands from consumers and the growing insertion of technology to support decision making, making the need for robust management processes imperative.

In this context, the processes and activities related to Production Planning and Control (PPC), gain relevance, as they are the ones that will enable the Production System (PS) to respond to demands efficiently (rational use of resources) and effective (achievement of objectives).

Burbidge (1981, p.21), a classic author in the area of PPC, already emphasized that the PCP "is the function of management related to the planning, direction, and control of the supply of materials and process activities in a company", that is, it is directly related to the essential activities of the PS.

Bonney (2000) notes that the PPC has been asked to respond both to internal changes that have occurred in organizations and to external changes, arising from the environment in which they are inserted, requiring quick responses, better control of resources and better performance in deliveries.

Aligned with this context, the present work aims to objective the report of a process of implantation, use and the developments resulting from a system of pointing the production.

In order to achieve the proposed objective, a bibliographic review was carried out on the topics of interest and a case study in a company that manufactures hospital medical equipment in the interior of the State of São Paulo.

The present work is structured in six sections, in the first, a brief introduction to the theme is presented, highlighting the general objective of the work. In the second section, a theoretical framework is presented, which supported the fieldwork. The third section is reserved for a discussion of the methodological procedures applied to carry out the work. In 
DOI: 10.14807/ijmp.v11i5.1299

the fourth section, the analysis and discussion of the results are presented. In the fifth section, the conclusions of the study are presented, followed by the bibliographic references used.

\section{THEORETICAL REFERENCE}

\subsection{Production Planning and Control (PPC)}

PPC is defined by Burbidge (1981) as a function of management that is related to the planning, direction, and control of material supply and process activities of a company. Zaccarelli (1986) expands and considers PPC to be a set of interrelated functions to commanding the production process and coordinating it with the other administrative sectors of the company.

Vollmann et al. (2006) add by citing that companies need PPC systems that can determine, transmit, review and coordinate needs through a global supply chain system.

According to Slack et al. (2018), PPC is considered one of the activities of Production Administration, which consists of establishing an operational plan to manage the activities of the productive operation and that can meet the demand of consumers operating continuously. Still according to these authors, in the general production management model, shown in Figure 1 , it is possible to observe where the PPC is positioned.

PPC activities have become more complex due to changes in the focus of control of individual production units for the coordination of complete supply chains. Together with the geographical dispersion of productive units, this fact brings together activities directly related to Business Logistics to fulfill this new scope of action (BONNEY, 2000; VOLLMANN et al., 2006).

Zhong et al. (2013) complement by citing the importance of the PPC is working with information in real-time. For them, this type of information is important for scheduling processes and coordinating work orders and operations considering the company's restrictions.

This reinforces the segmentation of PPC activities, proposed by Fernandes and Godinho Filho (2010), dividing them into activities related to Production Planning (PP) and Production Control (PC). In this light, the main objective of the PP is to match demand and capacity in the medium term, while the objective of the PC is to regulate the flow of materials in the short term.

Taking some studies as a reference (BURBIDGE, 1981; VOLLMANN et al. 1997; FERNANDES; GODINHO FILHO, 2010; SLACK et al., 2018), it can be observed that 
DOI: 10.14807/ijmp.v11i5.1299

regardless of the type of productive system adopted, the technology used in the process and the tool used to perform the administration to production, some activities are directly related to the realization of the PPC. Such activities are shown in Table 1.

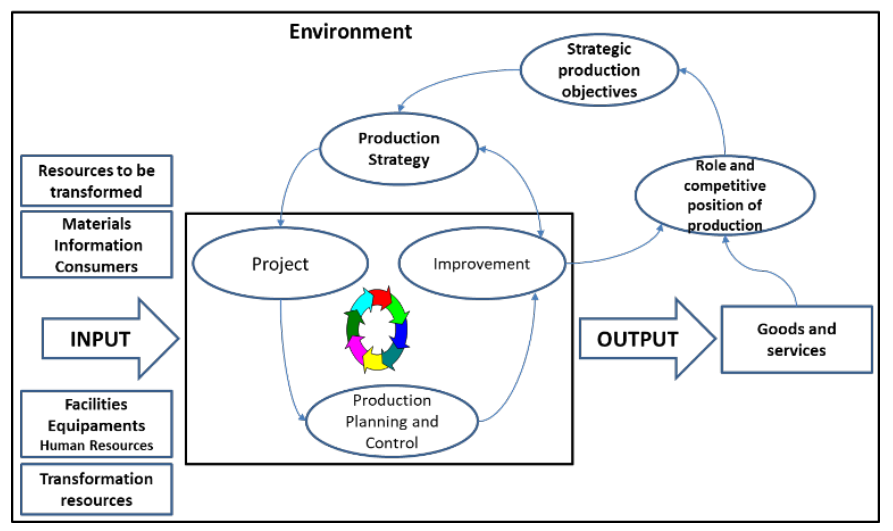

Figure 1: General Production Management Model

Source: Adapted for Slack et al. (2018)

Table 1: PPC Activities

\begin{tabular}{|l|l|}
\hline \multicolumn{1}{|c|}{$\begin{array}{c}\text { PRODUCTION PLANNING } \\
\text { (PP) }\end{array}$} & \multicolumn{1}{c|}{ PRODUCTION CONTROL (PC) } \\
\hline • Demand forecast & $\bullet$ Master programming \\
- Aggregate planning & - Capacity analysis \\
- Capacity planning & - Coordination of purchase and production orders \\
- Disaggregated planning & - Inventory control \\
& - Shop floor control \\
& $\boldsymbol{\sim}$ Release of orders \\
& $\boldsymbol{\sim}$ Operations programming \\
& $\boldsymbol{\sim}$ Production notes \\
\hline
\end{tabular}

Tubino (2017) points out that the data collection of some activities related to PC is easily automated through data collectors arranged at various control points, in order to facilitate the function of the PPC in ensuring that the issued production is executed.

Marçola (2000), cites an important factor that is the relationship between the activities of the CFP and the Demand Response Strategies (DRS). According to this author, ERDs define how manufacturing will respond to demand, mainly in terms of time. For him, each ERD must be applied to specific products and situations.

A detailed classification of ERD is proposed by Fernandes and Godinho Filho (2010). These authors present six ERDs that can be adopted in a Production System: Production to stock based on demand forecast (Make to Stock - MTS); Production to stock based on a quick replenishment of stock (Quick response to stock - QRTS); Assemble to Order (Assemble to Order - ATO); Custom production (Make to Order - MTO); Resources input to order (Resources to Order - RTO); Engineering / Project to Order (Engineering to Order - ETO). 
DOI: 10.14807/ijmp.v11i5.1299

Still, according to Fernandes and Godinho Filho (2010), the response time between placing an order and receiving it will depend on its lead times, which are determined according to the ERD used. That is, in an ETO Production System, its response time is the sum of the lead times for project design, material supply, item manufacturing, assembly, and distribution. For an ERD MTS, its response time is only the distribution lead time.

\subsection{Production Note}

For Lustosa et al. (2008), PC is responsible for directing and regulating the flow of materials throughout the manufacturing cycle, starting with the requisition of raw materials and extending to the delivery of the finished product. In this sense, it must provide instructions to the resources involved, to comply with the pre-established plan in the PP phase, optimizing the use of resources, inventories in process, manufacturing cycle and fulfilling predetermined dates.

Corrêa and Corrêa (2004) emphasize that the PC must monitor the development of the work to be carried out, the time and the quantity produced, constantly comparing the planned versus performed status, and promoting adjustments in plans and programs to correct any deviations caused by unpredictable factors that perhaps compromise the production performance and the execution of what was planned.

To Marçola and Andrade (2009), the PC must also provide feedback to the other organizational functions, meeting the information needs of the managers to make faster and more intelligent decisions in the production management process. The authors also point out that the activities of material planning, production scheduling, order release, negotiation of delivery dates, the formation of the real cost of transformation, capacity planning, among others, require constant interaction with the PC.

The production note is one of the activities included in the PC, as already indicated in Table 1 and its main activities are: collecting and recording the events that took place on the factory floor.

According to Marçola and Andrade (2009), depending on the characteristics of the production process and the functionalities of the systems existing on the factory floor, data collection is performed based on:

- Manufactured products - notes of the quantities of finished and intermediate products manufactured, with the entry into inventories in the management system 
DOI: 10.14807/ijmp.v11i5.1299

- Refuse and rework - notes of the quantities disapproved by quality control or the process in its respective stage of transformation, as well as notes of rework operations

- Operations and resources - notes of the dates and times of start and end of production operations and of the resources used in manufacturing (labor and equipment)

- Shutdowns of machines, equipment, and labor - notes of the dates and times of start and end of stops of machines and labor linked to the respective reasons for inactivity

- Operation of machines and equipment - identification of the operating regime (operating, loading, preparing, unloading, among others), machine speed, tool life, and other technical/operational parameters.

According to Corrêa and Corrêa (2004), it is essential that there are quality, availability, and precision in the data collected on the factory floor, collaborating for the construction of information and promoting the integration of business processes and consistency in the dismemberment and execution of plans

The events carried out by the productive resources must be collected, identifying temporal dimensions (start and end time), volume (quantity), quality (conforming and nonconforming) dimensions and relate them to activities performed (manufacturing order operations that consumed those resources). Subsequently, all this data must be recorded in the computer system used by the company, becoming information, providing the current status of the factory floor (MARÇOLA; ANDRADE, 2009).

Table 2 presents some classifications for the types of data collection and recording of the shop floor.

Table 2: Types of data collection and recording of the shop floor.

\begin{tabular}{|c|c|}
\hline Autor(es) & Classificação \\
\hline Jolesz (1987) & $\begin{array}{cl}\text { It deals with automatic data collection } \\
\text { and subdivides it into three categories: } \\
\checkmark & \text { Assisted manual } \\
\checkmark & \text { Semi-automatic } \\
\checkmark & \text { Fully automatic }\end{array}$ \\
\hline Rao (1996) & $\begin{array}{ll}\boldsymbol{v} & \text { Manual } \\
\boldsymbol{v} & \text { Supervisory } \\
\boldsymbol{v} & \text { Continuous } \\
\end{array}$ \\
\hline Favaretto (2002) & $\begin{array}{ll}\checkmark & \text { Manual } \\
\checkmark & \text { With collectors } \\
\checkmark & \text { Automatic collection }\end{array}$ \\
\hline Marçola and Andrade (2009) & $\begin{array}{ll}\boldsymbol{V} & \text { Manual } \\
\boldsymbol{V} & \text { Automatic }\end{array}$ \\
\hline
\end{tabular}

Source: Prepared by the authors. 
DOI: 10.14807/ijmp.v11i5.1299

Following the line proposed by Marçola and Andrade (2009), as it is presented in more detail, in Table 3, the proposed classification, its categories and characteristics are presented.

All authors dealing with the subject, emphasize the need for companies to implement systems that require the least possible intervention, guaranteeing the fidelity of the data, as well as avoiding errors resulting from the erroneous insertion of the data. Aspects that need to be addressed when deploying production scoring systems.

Table 3: Classifications, categories, and characteristics for the forms of pointing.

\begin{tabular}{|c|c|c|}
\hline Classificação & Categoria & Características \\
\hline \multirow{3}{*}{ Manual } & $\begin{array}{l}\text { Centralized } \\
\text { Manual }\end{array}$ & $\begin{array}{l}\text { Workers go to a Pointing Station, } \\
\text { usually in each factory cell, and ask } \\
\text { the pointer to open or close a } \\
\text { specific manufacturing order } \\
\text { operation }\end{array}$ \\
\hline & $\begin{array}{l}\text { Self-pointing } \\
\text { Written } \\
\text { Manual }\end{array}$ & $\begin{array}{l}\text { The productive resource operators } \\
\text { themselves fill out written forms, } \\
\text { cards or spreadsheets in each } \\
\text { productive sector in writing }\end{array}$ \\
\hline & $\begin{array}{l}\text { Computer- } \\
\text { aided self- } \\
\text { pointing }\end{array}$ & $\begin{array}{l}\text { Workers go to and from a computer, } \\
\text { using friendly features such as } \\
\text { command buttons, data list, special } \\
\text { function keys }\end{array}$ \\
\hline \multirow[b]{2}{*}{ Automatic } & $\begin{array}{l}\text { Semi- } \\
\text { automatic }\end{array}$ & $\begin{array}{l}\text { Workers take the product, document } \\
\text { or card to the sensors for the reading } \\
\text { to occur. The most common } \\
\text { applications are barcode readers and } \\
\text { magnetic cards }\end{array}$ \\
\hline & $\begin{array}{l}\text { Fully } \\
\text { automatic }\end{array}$ & $\begin{array}{l}\text { Fully automatic data collection does } \\
\text { not require operator intervention. } \\
\text { From direct electronic connections } \\
\text { with sensors, controllers and } \\
\text { actuators installed in productive } \\
\text { resources, data acquisition takes } \\
\text { place in real time }\end{array}$ \\
\hline
\end{tabular}

Source: Made from Marçola and Andrade (2009).

\section{METHODOLOGICAL PROCEDURES}

\subsection{Research Method}

One of the main characteristics of qualitative research is cited by Zanella (2009) as the non-use of statistical instruments in the analysis of the data. For him, the basis is to have theoretical-empirical knowledge that allows attributing scientificity. Its main characteristics are natural environment being the direct source of the data; researcher as a key instrument; descriptive research; concern with the process and not with the results and products; a trend of intuitive data analysis; concern with meaning seeking to understand the phenomena. Birochi (2015) highlights that it is not necessary to quantify the studied phenomena 
DOI: 10.14807/ijmp.v11i5.1299

The most appropriate research methods in conducting qualitative research, according to Nakano (2012), are action research and case study. What differentiates these two methods is the degree of involvement of the researcher with the company, with individuals and the implication of the research in organizational changes. It is possible to add, according to Yin (2005), that the case study has an empirical character and, in addition to investigating a phenomenon in its real context, it assumes that the boundaries between the context and the phenomenon are not clearly defined.

Based on these definitions, this work was structured in the form of a case study. Data collection occurred through the analysis of the implementation process and the use of the company's appointment system, interviews with the main stakeholders and those responsible for the processes, in addition to observations of the production processes and analysis of documents.

\subsection{Company Object of the Study Characterization's}

The analysis unit is a metal-mechanic industry located in the interior of the state of São Paulo of medium size in relation to the number of employees (less than 100 employees). Founded in 1975, the company manufactures equipment for the sterilization of health products, such as surgical instruments, clothing, among others. The company is certified for its Quality Management System based on ABNT NBR ISO 9001: 2015 and ABNT NBR ISO 13485: 2016 standards

The manufacturing layout of its products is classified as being by processes or functional (job shop), where there is the formation of departments or sectors specialized in the performance of certain tasks, where the productive resources and similar operations are grouped creating dedicated sections (NEUMANN; SCALICE, 2015). This type of layout is recommended when the production volume is low or intermediate and there is a wide variety of products, the case of the company being studied.

The predominant demand response strategies in the company are MTS and MTO, according to the product lines and the level of demand in specific periods of the year.

Before the year 2012, the activities carried out for the production of the items and subsets of the products were registered by the operators themselves in printed forms described as 'Manufacturing Order' (MO), where they contained the sequence of the production process with description of the necessary productive resource, the preparation time and execution time of the activity and a short instruction for the operator. When completed, each MO was filed in 
DOI: 10.14807/ijmp.v11i5.1299

print due to a regulatory requirement applicable to the company. There was no check if the number of pieces required in the MO was carried out, much less was it checked if the time of carrying out the activity corresponded to the estimated time described in the MO, which generated problems such as (BRAGA; ANDRADE, 2012):

- Not all employees recorded production times

- The times defined for each operation did not match the actual production time of the part / product

- It was not possible to determine which operator performed a particular operation

- The reasons for inactivity were not recorded;

- Absence of indicators for monitoring and controlling the appointment of production

- Many manufacturing / assembly routes not in accordance with the technological sequence (inadequate ordering or lack of necessary operations)

- Time information received late at the PPC, times only returned after completion of all MO operations.

In view of the above, the company's managers decided to implement a system for recording production in an attempt to minimize and, if possible, eliminate these problems. For that, a specialized consultancy was hired to support the process of defining and implementing the production appointment

\section{RESULTS ANALYSIS AND DISCUSSION}

\subsection{The Process of Implementing and Using the labor appointment system}

The implementation of the labor appointment system (LAS) took place in 2012 as reported in an article by Braga and Andrade (2012). At the time, some improvements were described by the authors that could be seen in just five months of using the LAS manually, such as:

- Registration of items and preparation of manufacturing routes for all parts manufactured by the company

- Correction of manufacturing scripts with outdated or incorrect activities

- Statement of total productive hours and total inactive hours reported monthly. 
DOI: 10.14807/ijmp.v11i5.1299

What was not evidenced by the authors at the time were the difficulties with maintaining the implemented LAS, which are exposed below:

- Every employee used an appointment card per day, where at the end of the shift it was deposited in an urn. The next day, an employee hired specifically to control these cards, collected them and transcribed the information to the company's ERP system. This activity required approximately 7 hours to be performed, due to the high volume of data generated, in addition to the necessary stops to check errors made in the notes;

- After carrying out the previous activity, the employee was responsible for preparing the appointment cards for the following day, identifying the employee's name and date on each card. The cards should also be placed in the card holder of each employee;

- The cards were stored for at least two years due to the regulatory requirement applicable to the company, which required considerable physical space.

In addition to these daily difficulties, manual appointment provided other obstacles for the company:

- As the recording of the appointment in the ERP system happened only on the next day, it was not possible to check the appointment errors on the same day. It was also not possible to know in real time the status of the appointments and which employees were not carrying out the appointment in real time;

- The manual registration did not allow checking the situation in which the pieces were in the production process, in addition, this form of registration allowed the employee to register the appointment retroactively in case of forgetfulness. It was also possible to erase the card, changing information already registered, which doubted the fidelity of the registration.

The LAS worked manually until 2014, when the company opted to look for alternatives to improve the scoring system, aiming to eliminate the problems previously described.

Among the available alternatives, those responsible for the company's production opted for a semi-automatic pointing system, that is, with the use of computerized terminals (collectors) distributed on the factory floor, where the employee should go to this collector to perform the pointing. 
DOI: 10.14807/ijmp.v11i5.1299

The implementation of this system required investment on the part of the company under study, as there was the acquisition of the collectors (initially three units), software licenses, operational training, implementation and expenses with the technicians of the company that developed the solution. The implementation took approximately three weeks and included at least the exclusive dedication of two internal company employees and consultants.

Among the difficulties faced during the implementation process, the following stand out:

- Another cultural change for employees, as they were used to manually registering. Now the registration would be performed electronically. As simple and intuitive as it was to make the appointment at the collector, many employees did not have knowledge in computers or any other electronic device, making training more timeconsuming and specific, in addition to individualized monitoring for a significant period of time;

- The semi-automatic system contracted was aimed at controlling productive resources, that is, equipment. The company had the challenge of adapting the system to allow control of the allocation of labor. This adaptation was seen as the biggest challenge in the implementation process, as not even the company that developed the solution had made such adaptation in another client;

- The communication between pointing software and the company's ERP was difficult, given the lack of commitment of the company that developed the solution to adopt alternatives for this communication. This communication was adopted since the production centers, the manufacturing routes, the sequencing of operations, among other information are contained and controlled by the company's ERP;

- The technical support of the company that developed the solution was not agile, where reported problems were often verified and solved after many days of opening the call. This problem made it impossible to use the appointment system, which is extremely harmful, considering the culture that has been in place since 2012 of faithful appointment of the appointment until the end of the workday.

At the end of the implementation period of the new appointment system, the company started an improvement process arising from the use of this new configuration of the systems involved, which are highlighted below. 


\subsection{Developments in the use of the LAS}

The semi-automatic pointing system brought several benefits to the company, the following being highlighted:

- The new system does not allow to make notes retroactively and it is also not possible to change the times indicated, thus guaranteeing the integrity of the information;

- The measurement of labor efficiency was not performed by the previous system (manual). It was then possible to measure this efficiency, taking into account the workload of the employee, comparing it with his daily appointment. An indicator was developed for its measurement, and the initial target was set at 92\%.

- It was also possible to measure the use of labor, that is, taking into account the workload of the employee, how much of that time the employee was productive, that is, did activities related to the transformation of the product. An indicator was developed to measure this utilization rate, with the initial target being set at $90 \%$;

- The previous system already made it possible to measure the times related to productive and inactive hours, however the new system allowed to collect these values more quickly. An indicator was developed to measure the percentage of productive hours and inactive hours, with the limit for inactive hours being set at $10 \%$;

- Using a software feature of the company that developed the solution, called 'Dashboard', the person in charge of production is able to instantly view the notes being made on the factory floor. It is possible to check employees who are not logged in to the system, that is, they are not making any notes (productive or not). It is also possible to know in which stage of the production process a manufactured item is, bringing in real time the status of production.

The script times defined in the manufacturing orders could be compared with the notes made. Through the issuance of a report in the company's ERP system, the person in charge of production is able to visualize the activities whose times (estimated versus realized) differ by more or less than $15 \%$, a value defined as acceptable by the company. In this way it is possible to check if there was any problem with the performance of the activity or to correct the routing times of the manufacturing orders. 
DOI: 10.14807/ijmp.v11i5.1299

\section{CONCLUSIONS}

The theoretical framework presented in the present work shows the importance of the activities of the PPC for the proper management of the production process, with emphasis on the PC, which has a fundamental role for the plans and objectives to be realized.

Such management requires a set of data and information that allows the manager to make decisions that result in an increase in the efficiency and effectiveness of the Productive System, an aspect that can be achieved through a robust system of production reporting.

The implementation and use of the aforementioned pointing system, in the company under study, allowed an evolution regarding Production Management, providing subsidies for a real-time and detailed analysis of the events that demand action from the production manager and allow an action proactive role of the PPC with respect to the PC.

The very evolution of the pointing system, from manual to semi-automatic selfpointing, has already demonstrated a gain in maturity of those involved in the process and the company's controls. This evolution allowed the addition of new metrics and performance indicators in the process. The fact that such actions need to be seen as strategic by companies is highlighted, in view of the time involved to achieve more expressive results, as demonstrated in the study and the necessary investments.

As a proposal for future studies, the authors point out the need to disseminate such practices among Brazilian industrial companies, considering that in a context where the transition to Industry 4.0 or the fourth industrial revolution is discussed, many companies suffer from specific problems and chronic ones, such as the lack of an adequate indication of production - an aspect theoretically solved a few decades ago, which evidences a gap between PPC theory and practice in organizations.

\section{REFERENCES}

ANDRADE, J. H. (2013) Propostas para a melhoria da integração entre desenvolvimento de produto e planejamento e controle da produção em ambiente ETO. Tese de doutorado. Universidade Federal de São Carlos.

BIROCHI, R. (2015) Metodologia de Estudo e de Pesquisa em Administração. Florianópolis: UAB. 134 p.

BONNEY, M. (2000) Reflections on production planning and control (PPC). Revista do Departamento de Engenharia de Produção - Gestão \& Produção, Universidade Federal de São Carlos, v. 7, n. 3, p. 181-207.

BRAGA, F. A. S.; ANDRADE, J. H. (2012) Planejamento e controle da produção: relato do processo de implantação e uso de um sistema de apontamento da produção. In: XXXII Encontro Nacional de Engenharia de Produção. Bento Gonçalves-RS. 
BURBIDGE, J. L. (1981) Planejamento e Controle da Produção. São Paulo: Atlas. CORREAA, H. L; CORRÊA, C. A. (2004) Administração de Produção e Operações. São Paulo: Atlas.

FAVARETTO, F. (2002) Considerações sobre o apontamento da produção. In: XXII Encontro Nacional de Engenharia de Produção. Curitiba.

FERNANDES, F. C. F.; GODINHO FILHO, M. (2010) Planejamento e controle da produção - dos fundamentos ao essencial. São Paulo: Editora Atlas.

JOLESZ, G. (1987) Lies, Damned lies and statistics - the case for automatic Data Collection. BPICS Control, p. 17-19, December/January.

LUSTOSA, L. (2008) Planejamento e Controle da Produção. Rio de Janeiro: Elsevier.

MARÇOLA, J. A. (2000) Horas anualizadas como técnica do planejamento da capacidade em sistemas de manufatura. Tese de doutorado. Escola de Engenharia de São Carlos - USP.

MARÇOLA, J. A.; ANDRADE, J. H. (2009) Melhorias no processo de apontamento manual da mão-de-obra em ambientes de produção Engineer-to-Order - um estudo de caso. In: XVI Simpósio de Engenharia de Produção. Anais....Bauru-SP.

NAKANO, D. (2012) Métodos de Pesquisa Adotados em Engenharia de Produção e Gestão de Operações. In: MIGUEL, P. A. C. Metodologia de pesquisa em engenharia de produção e gestão de operações. $2^{\mathrm{a}}$ ed. Rio de Janeiro: Elsevier.

NEUMANN, C.; SCALICE, R. K. (2015) Projeto de Fábrica e Layout. $1^{\text {a }}$ Ed. Rio de Janeiro: Elsevier.

RAO, B. K. N. (1996) Handbook of condition monitoring. 1a ed., Elsevier Science Ltd.

SLACK, N.; BRANDOM-JONES, A.; JOHNSTON, R. (2018) Administração da produção. 8 ed. São Paulo: Atlas.

TUBINO, D. F. (2017) Planejamento e Controle da Produção: teoria e prática. 3 ed. São Paulo: Atlas.

VOLLMANN, T. E.; BERRY, W. L.; WHYBARK, D. C.; JACOBS, F. R. (2006) Sistemas de planejamento e controle da produção para gerenciamento da cadeia de suprimentos. 5. ed. Porto Alegre: Bookman.

YIN, R. K. (2005) Estudo de Caso - Planejamento e Métodos. $3^{\text {a }}$ ed. Porto Alegre: Bookman.

ZACCARELLI, S. B. (1986) Programação e controle da produção. 7a. ed. São Paulo: Pioneira.

ZANELLA, L. C. H. (2009) Metodologia de Estudo e de Pesquisa em Administração. Florianópolis: Departamento de Ciências da Administração/UFSC, Brasília,164 p.

ZHONG, R. Y.; DAI, Q. Y.; QU, T.; HU, G. J.; HUANG, G. Q. (2013) RFID-enabled realtime manufacturing execution system for mass-customization production. Robotics and Computer-Integrated Manufacturing, v. 29, p. 283-292. 